DOI https://doi.org/10.30525/978-9934-26-007-0-15

\title{
ПОНЯТІЙНО-ПРАВОВЕ МИСЛЕННЯ В ДАВНІЙ ГРЕЦІї: АРИСТОТЕЛЬ. ПРОЛЕГОМЕНИ ДО НАУКИ ПОНЯТЬ
}

\author{
Кучеренко Д. С., Гамбург Л. С.
}

\section{ВСТУП}

Життя і творчість Аристотеля припадає на IV ст. до н. е., коли культура вільних давньогрецьких міст-держав класичного періоду сягає найвищого розквіту. На його долю випадає місія узагальнення праці, підбиття підсумку досягнень філософів і науковців Давньої Греції та передання їхнього знання наступним поколінням. Аристотель виконує це титанічне завдання. Він стає першим мислителем-енциклопедистом, який створює всебічну систему філософії, що охоплює всі сфери людського розвитку, закладає основи науки та наукового мислення.

К. Маркс називає Аристотеля «генієм», «велетнем думки» та «найвеличнішим мислителем давнини» ${ }^{1}$. На значення Аристотеля для філософії та науки вказує О.Ф. Лосєв: «Аристотель має довготривалу історію у надрах європейської філософії. Здається, не було жодного століття, жодної філософської школи, яка б так чи інакше, у тій чи іншій мірі, не пов'язувалася 3 Аристотелем» ${ }^{2}$. Стагірит визнається засновником класичної (формальної) логіки, творцем понятійного апарату, який і дотепер пронизує філософський лексикон і стиль наукового мислення. Проте його філософська та наукова думка про понятійне (діалектичне) мислення до нашого часу так і не стала предметом серйозних наукових досліджень. У цьому аспекті актуальним $\epsilon$ зауваження О.Ф. Лосєва: «Дивовижно, що розвитком думки самого Аристотеля майже не займалися, тоді як про Платона у цьому відношенні написано дуже багато» ${ }^{3}$. В.І. Ленін, розуміючи могутній творчий потенціал Аристотеля та віддаючи данину його внеску у розробку понятійного (діалектичного) мислення, незатребуваного науковою спільнотою, пише: «Маса архіцікавого, живого, наївного (свіжого), що вводить у філософію та у викладах замінюваного схоластикою, підсумком еtс. Поповщина вбила в Аристотелі живе та увічнила мертве. <...> Схоластика та поповщина взяли мертве в Аристотеля, а не живе: запити, шукання, лабіринт, <..> Логіка

\footnotetext{
${ }^{1}$ Маркс К. Капитал. Т. І. Маркс К., Энгельс Ф. Соч. 2-е изд., т. 23. Москва. 1960. С. 70, 92, 419.

2 Лосев А.Ф. Очерки античного символизма и мифологии / Сост. А.А. Тахо-Годи; Общ. ред. А.А. ТахоГоди и И.И. Маханькова. Москва : Мысль. 1993. С. 710.

3 Лосев А.Ф. История античной эстетики. Аристотель и поздняя классика. Харьков : Фолио; Москва: ООО «Издательство АСТ», 2000. С. 13. (Вершины человеческой мысли).
} 
Аристотеля є запит, шукання, підхід до логіки Гегеля, а 3 неї, із логіки Аристотеля (який всюди, на кожному кроці ставить питання саме про діалектику), зробили мертву схоластику, викинувши всі пошуки, вагання, прийоми ставлення питань. Саме прийоми ставлення питань, ніби пробні системи були у греків, наївне різноголосся, чудово відображуване в Аристотеля» ${ }^{4}$. Метою дослідження $\epsilon$ порівняння підходів Платона та Аристотеля до понятійного мислення, розкриття низки заперечень Аристотеля проти «теорії ідей» Платона, розгляд основних положень альтернативної теорії пізнання, висунутої Аристотелем. Із творчого спадку Аристотеля вбачається, що філософ не розробляє окремого вчення про поняття та їхні визначення. Він намагається реформувати філософію пізнання Сократа і Платона в теорію, яка би пояснювала світ явищ. Вихідним пунктом філософії Аристотеля, спрямованої на розв'язання цього завдання, стає шлях, намічений Сократом - понятійне пізнання. Проте, на відміну від поетичних діалогів Платона, насичених міфами, образами, метафорами, тексти творів Аристотеля, що дійшли до нашого часу, характеризуються лаконічним, строгим і трудним для сприйняття стилем викладу. Це пов'язано із тим, що Аристотель відхиляє художній контекст платонівських діалогів, оскільки, на його думку, той перешкоджає проясненню та розв'язанню гносеологічної проблематики: «Ті, хто втілює свої мудрування у форму міфів, не варті серйозної уваги» ${ }^{5}$.

\section{1. Критика «теорії ідей» Платона}

У філософській та ранньонауковій думці Давньої Греції IV ст. до н. е. загальновизнаними природними сутностями, що чуттєво сприймаються, визнаються вогонь, земля, вода, повітря, рослини, тварини, Всесвіт та його частини. Поряд із зазначеними сутностями Платон визнає сутностями ідеї (ейдоси), на обгрунтування існування яких розробляє спеціальну онтологічно-гносеологічну теорію. Ця теорія пояснює сутність філософського знання, шлях його досягнення і сам предмет знання. Платон виходить iз того, що оскільки до єдиного (одного) долучається множина, тому ідеї $\epsilon$ сутностями, пов'язаними із загальним і родом. Він стверджує, що рід $\epsilon$ у більшій мірі сутністю, ніж види, а загальне - у більшій мірі, ніж одиничне. Філософія найвідомішого учня Платона - Аристотеля (384-322 рр. до н. е.) витікає із філософії Платона, оскільки вони «філософи умоглядні, які виходять $з$ основних начал Сократа $<\ldots>$ мають однаковий погляд на саму

\footnotetext{
4 Ленин В.И. Полное собрание починений. Издание пятое. Том 29. Философские тетради. Москва : Издательство политической литературы, 1969. С. 325-326.

${ }^{5}$ Аристотель. Сочинения в четырех томах. Т. 1. Ред. В.Ф. Асмус. Москва : «Мысль», 1976. (АН СССР. Ин-т философии. Филос. наследие). С. 111.
} 


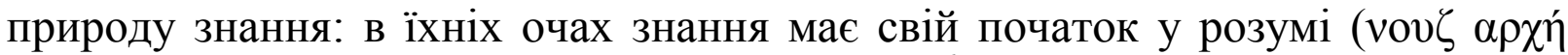
$\varepsilon \pi 1 \sigma \tau \eta \mu \eta \zeta)$, у поняттях, а не у відчуттях» ${ }^{6}$. Платон шукає онтологічні підстави понять і стверджує, що такі визначення не належать чуттєвому сприйняттю, а належать іншому, яке він називає ідеями. На думку Платона, «самі по собі» (грец. to kath' hayto), тобто самостійно, існують умосяжні сутності (ідеї, ейдоси, роди, види, математичні об'єкти), а сутності, що сприймаються чуттєво (одиничні речі), до них доєднуються. Аристотель вказує: «Платон вважає ейдоси та математичні предмети двома родами сутності, а третім - сутність тіл, що чуттєво сприймаються» ${ }^{7}$. Уже давньогрецькі мислителі, зокрема піфагорійці, усвідомлюють, що число перебуває між чуттєвим і мисленим. Щодо співвідношення вказаних сутностей у Платона Аристотель зазначає: «Далі Платон стверджував, що, окрім того, що сприймається чуттєво та ейдосів існують як щось проміжне математичні предмети, що відрізняються від тіл, які сприймаються чуттєво, що вони вічні і нерухомі, а від ейдосів - тим, що є багато однакових таких предметів, у той час як кожний ейдос сам по собі тільки один» ${ }^{8}$. Платон для розв'язання проблеми існування людського знання виходить із того, що воно пов'язане з речами, оскільки є знанням про світ, проте воно існує незалежно від речей. У діалозі «Парменід» відокремленість знання від речей філософ пояснює припущенням про можливість існування певних носіїв цього знання, які він називає ейдосами. Існування ідей як відокремлених сутностей мислення Платон обгрунтовує 3 огляду на дві можливості розуміння того, що таке думка. По-перше, думка - це думка про щось, тобто вона завжди спрямовується на пошук певних смислів (динамічний аспект). По-друге, думка є чимось самостійним, певною сутністю - ідеєю «самою по собі» (статичний аспект). Платон, зважаючи на настанову Сократа про пошук загального, вказує на те, що ейдоси необхідно розглядати не тільки щодо речей, а й у відношеннях між собою. Проблему ейдосів Платон розв'язує в діалозі «Софіст», в якому доходить висновку, що ейдоси $є$ «родами» (одне), до яких долучаються «види» (множина). Світ ейдосів від світу речей у нього відокремлюється простором (просторова відокремленість) (грец. khoriston відокремлене, від khora - місце). В ейдосах Платон не розрізняє: 1) роди та види, 2) категорії («сутність», «кількість», «якість» і т.д.), 3) загальні поняття («добро», «справедливість» тощо).

Аристотель спершу намагається точно визначити свою позицію щодо «теорії ідей» Платона. Він піддає критиці теорію Платона про ідеї та висуває

\footnotetext{
${ }^{6}$ Трубецкой С.Н. История древней философии. Часть вторая. Москва : Издательство: Типолитография Товарищества И.Н. Кушнерев и Ко, 1908. С. 59.

${ }^{7}$ Аристотель. Сочинения в четырех томах. Т. 1. Ред. В.Ф. Асмус. Москва : «Мысль», 1976. (АН СССР. Ин-т философии. Филос. наследие). С. 188-189.

${ }^{8}$ Там само. С. 79.
} 
альтернативну теорію пізнання. Аристотель вказує, що ідея має два аспекти, по-перше, аспект буття, а, по-друге, аспект визначеності: «<..> суть буття (to ti en einai) речі $\epsilon$ саме суть (ti en einai) $\dddot{\text { ii }}<\ldots>>{ }^{9}$. Критика «теорії ідей» Платона викладена у «Метафізиці» (грец. Ta meta ta physika - те, що після фізики) - збірнику порівняно самостійних творів Аристотеля, об'єднаних проблематикою тієї науки, яку він називає першою філософією. Для Аристотеля також центральним $є$ питання про значення понять для буття та знання. Проте Аристотель стверджує, що «самі по собі» існують лише сутності, а саме «перші сутності», тобто ті, що існують як одиничні. Умосяжне (поняття) існує виключно через «перші сутності», тобто доєднується до них. Він критикує Платона та зазначає, що у поняттях (в їхньому сучасному розумінні) необхідно розрізняти: роди та види, категорії та загальні поняття. Аристотель відмовляється від поняття «ейдос» і вводить поняття «усія» (грец. оуsia - сутність), яке у загальному вигляді визначає так: «Сутність $є$ і матерія, і форма, і те, що з них» ${ }^{10}$. Термін «сутність» він використовує в кількох значеннях: 1) сутність буття (грец. to ti en einai) (poc. «чтойность» у перекладі О.Ф. Лосєва): «<...> суть буття кожної речі означає те, що ця річ є сама по собі» ${ }^{11}$ 2) загальне (грец. katholoy): «<..> те, що говориться про одиничні речі» 12 ; 3) рід (грец. genos): «Основна частина визначень при позначенні суті речі $<\ldots>$ видові відмінності якого позначають властивості» ${ }^{13}$; 4) першооснова (грец. hypokeimenon): «<...> те, про що говориться все інше, у той час як сам він уже не говорить про о інше» ${ }^{14}$, тобто, те, що лежить в основі одиничних речей. У значеннях загального та роду сутність $\epsilon$ поняттям. Під формою Аристотель розуміє, по-перше, просторові обриси, по-друге, сутність у матерії. При цьому він розрізняє два смисли відокремленості: просторову та мисленнєву. Сутності відокремлені простором. За допомогою мислення можна зробити як певні розрізнення усередині окремої сутності, так і відокремити від неї форму (мислену форму - категорії та загальні поняття). Аристотель класифікує способи мислення усередині сутності на: 1) роди і види, 2) категорії, 3) загальні поняття. Таким чином, критика Аристотелем «теорії ідей» Платона зводиться до того, що останній гіпостазує (грец. hypostasis сутність) поняття, тобто розглядає їх як сутності (в розумінні Аристотеля), а саме: відокремлює їх у просторі і наділяє самостійним існуванням.

\footnotetext{
${ }^{9}$ Аристотель. Сочинения в четырех томах. Т. 1 / Ред. В.Ф. Асмус. Москва : «Мысль», 1976. (АН СССР. Ин-т философии. Филос. наследие). С. 192.

10 там само. С. 204-205.

${ }^{11}$ Там само. C. 191.

12 Там само. С. 110.

13 там само. C. 176.

14 там само. С. 189.
} 
Аристотель заперечує проти цього твердження Платона та зазначає, що існує лише мислена відокремленість сутності від форми (світу від знання). Таким чином, «відокремленість» необхідно розуміти тільки як мисленнєву (грец. kata logon), тобто відокремлення визначенням.

Аристотель переглядає діалектичний метод Платона, пояснює структуру буття, у тому числі, у сфері понять. За допомогою діалектичного методу Аристотель узагальнює накопичені попередниками знання, всебічно їх розвиває та досліджує під кутом зору поняття - їхнього понятійного значення. Г.В.Ф. Гегель пише: «Розум Аристотеля осягнув усі сторони та сфери реального універсуму і підпорядкував поняттю їхнє розсіяне багате різноманіття» ${ }^{15}$. Потім переходить до формулювання проблем, їхнього обговорення та розв'язання. Звернення до інших філософів необхідне Аристотелю для обгрунтування власних поглядів на той чи інший предмет, його читання - завжди полемічна інтерпретація, визначена досліджуваною проблематикою. На відміну від учителя, Аристотель не зупиняється на різкому протиставленні світу ідей світу явищ. Він не відокремлює ідеї та явища, загальне та окреме, а поєднує їх. На методологічне значення пояснення загального як у бутті, так і у пізнанні Аристотель вказує у «Метафізиці»: «Не має залишитися непоміченим, які суть буття речі та ii визначення, оскільки досліджувати без них - це все одно що не робити нічого» ${ }^{16}$. За вченням Аристотеля існують лише окремі речі. Загальні (родові) поняття $\epsilon$ тільки якостями речей, спільними багатьом речам, в яких вони лише і можуть існувати. Загальне існує не окрім «множини», а разом із нею, тому загальне, ідеї, не можна відокремлювати, зараховувати їх до якоїсь незалежної від явищ окремої дійсності. Відповідно до «теорії ідей» дотичні речі нашого світу існують тоді, коли вони є частиною ідей. Аристотель говорить, що саме слово «причетність» - це пуста метафора, яка нічого не пояснює. Незрозуміло, як ідеї можуть бути зумовлені через речі нашого світу. Обидва філософи вважають, що існує щось, що $є$ формою та суттю речей. Проте Платон вважає, що суть речей перебуває на надчуттєвому рівні, який міститься по той бік матеріального світу, а Аристотель - що суть речей перебуває на чуттєвому рівні, випливає з їхньої природи та міститься в матеріальному світі. Аристотель критикує вчення Платона про існування ідей окремо від речей та вказує, що це призводить до подвоєння існуючих сутностей: «Немов хтось, зажадавши підрахувати, при найменшій кількості речей вважав, що це буде тому не під силу, а

\footnotetext{
${ }^{15}$ Гегель Г.В.Ф. Сочинения: в 14-х т. / Г.В.Ф. Гегель; пер. с нем. Б.Г. Столпнер. Ленинград : Партийное издательство, 1932. Т. 10, Кн. 2. Лекции по истории философии. С. 224.

${ }^{16}$ Аристотель. Сочинения в четырех томах. Т. 1. Ред. В.Ф. Асмус. Москва : «Мысль», 1976. (АН СССР. Ин-т философии. Филос. наследие). С. 181.
} 
збільшивши їхню кількість, увірував, що підрахує» ${ }^{17}$. Тобто $є$ речі, що пізнаються нами у чуттєвому досвіді, а Платон додає до них ще надчуттєві речі, але не пояснює, як останні породжують чуттєві речі. Платон лише говорить, що чуттєві речі причетні до надчуттєвих речей, проте він не пояснює, що таке причетність. Аристотель вказує, що ідеї не можна мислити окремо від речей, оскільки вони містяться в речах: «< ..> слід < ..> вважати неможливим, щоб окремо одне від одного існувала сутність і те, сутністю чого вона є; як можуть через це ідеї, якщо вони сутності речей, існувати окремо від них?» ${ }^{18}$. Він зазначає: «Жоден із способів, яким доводять, що ейдоси існують, непереконливий. <...> Адже згідно з «доказіами від знань» ейдоси мали би бути для всього, про що є знання; на підставі доводу щодо «єдиного у множині» вони мали б утворюватися i для заперечень, а на підставі доводу, що «мислити щось можливо і після його зникнення», для минущого $<\ldots>»{ }^{19}$. Аристотель підкреслює: «Оскільки протилежності відмінні (hetera) за видом, а минуще i неминуще являють собою протилежності $<\ldots>$, то минуще і неминуще мають бути різними за родом. $<\ldots>$ Однак про ейдоси говорять, що вони тотожні за видом одиничним речам і не тільки мають одне 3 ними ім'я; проте те, що різниться за родом, ще більш віддалено перебуває від іншого, ніж те, що різниться за видом» ${ }^{20}$. Він звертає увагу на те, що оскільки ідеї у Платона $\epsilon$ онтологічною реальністю та як істинно існуюче, як оригінали речей, вони нерухомі, то теорія Платона не дає змоги пояснити постійний рух і зміну предметночуттєвого світу: «<...> вони для цих речей не $\epsilon$ причиною руху або будьякої зміни $<\ldots>$ вони нічого не дають ні для пізнання всіх інших речей (вони ж і не сутності цих речей, інакше вони були б усередині них), ні для їхнього буття (оскільки вони не перебувають у причетних до них речах)» ${ }^{21}$. Аристотель показує, що платонівські ідеї мисляться 3 огляду на властивості конкретних чуттєвих реальностей, наприклад, «справедливість» справедливого вчинку. Проте саме тому важко помислити, щоб ідеї були онтологічно відділені від конкретних речей, що беруть від них свої найменування. Аристотель запитує: «Ну, а чому, ніхто із тих, хто визнає ідеї не пропонує визначення якої-небудь ідеї?» ${ }^{22}$. Та відповідає на це запитання: «Не можна дати визначення будь-якій ідеї, оскільки ідея, як стверджують [ті, хто визнає ідеї], $\epsilon$ щось одиничне та існує окремо» ${ }^{23}$. Також вказує, що ідеї не здатні нічого пояснити, оскільки вони містять ті ж ознаки, що й

\footnotetext{
${ }^{17}$ Аристотель. Сочинения в четырех томах. Т. 1. Ред. В.Ф. Асмус. Москва : «Мысль», 1976. (АН СССР. Ин-т философии. Филос. наследие).. С. 328.

18 Tам само. С. 330 .

19 там само. С. 328.

${ }^{20}$ там само. С. 271.

${ }^{21}$ там само. С. 330.

${ }^{22}$ там само. С. 219.

${ }^{23}$ Там само. С. 217-218.
} 
явища зовнішнього світу: «<..> визнають ейдоси ні чим іншим, як речами, наділеними вічністю, що чуттєво сприймаються» ${ }^{24}$. Виходячи із зазначеного Аристотель доходить висновку, що у дійсності річ і поняття про неї невіддільні одне від одного та становлять одне і те ж: «<..> необхідно, мабуть, вважати неможливим, щоб окремо одне від одного існували сутність і те, сутність чого вона $\epsilon<\ldots>\gg{ }^{25}$.

\section{2. Онтологія понять. Гілеморфізм}

В Академії Платона Аристотель оволодіває діалектичним методом мислення, а саме: розрізненням, співставленням та аналізом понять, виявленням усіх значень, які може мати слово. Згідно із цим методом поняття визначається через свою протилежність, наприклад, єдине через множинність, множинність - через єдине. При цьому буття протилежностей має місце лише в їхній співвіднесеності, тому ідеї існують тільки у системі відношень. Будь-яке поняття отримує свій зміст через відношення до своєї протилежності, тим самим вибудовується система відношень, у межах якої тільки і мають смисл усі поняття, що підлягають визначенню. Платон встановлює протилежність між сутністю та бутністю (грец. genesis), а також допускає протилежність між мисленням (грец. logos) і відчуттям (грец. aisthēsis).

Аристотель виступає проти цього методологічного принципу. Первинну умову будь-якого мислення Аристотель вбачає у недопустимості безпосереднього поєднання протилежностей. Недотримання вказаної умови робить неможливим наукове пізнання. Протилежності, зазначає Аристотель, не можуть виступати началом усіх речей: «Жодна протилежність не $\epsilon$ начало у власному розумінні слова, а щось інше $\epsilon$ таке начало» ${ }^{26}$. Він вказує, що все що існує, не може народжуватися із взаємодії протилежних начал, оскільки протилежності не можуть впливати одна на одну. Між ними має перебувати щось третє, яке Аристотель позначає терміном «першооснова» (грец. hypokeimenon - те, що лежить знизу, в основі). Першооснова $\epsilon$ посередником між протилежностями, тобто, за Аристотелем, протилежності - це те, що говориться про першооснову: «<..> не кожний <..> справедливий чи несправедливий, а мається і щось середнє між ними» ${ }^{27}$. У разі ж поєднання протилежностей без першооснови матиме місце протиріччя: «<..> адже протиріччя означає саме таке протиставлення, в якому одна з обох сторін притаманна будь-якій речі, тобто не має нічого

\footnotetext{
${ }^{24}$ Аристотель. Сочинения в четырех томах. Т. 1 / Ред. В.Ф. Асмус. Москва : «Мысль», 1976. (АН СССР. Ин-т философии. Филос. наследие) С. 105.

${ }^{25}$ Там само. С. 88.

${ }^{26}$ Там само. С. 350.

27 там само. С. 172.
} 
проміжного $<\ldots>$ » ${ }^{28}$. Аристотель вказує: «<..> [необхідне] знання про щось $€$ знання загального. $<\ldots>$ А наука всюди досліджує головним чином перше те - від чого залежить інше і через що це інше отримує свою назву» ${ }^{29}$.

Недоліком платонівської наукової програми Аристотель вважає iі односторонність через відсутність у ній природно-наукових досліджень. Діалектика як наука про поняття поступово втрачає для філософа те методологічне значення, яке вона мала для Сократа і Платона. Аристотель звертається до грецької традиції натурфілософії, а його мислення грунтується на сприйнятті, спостереженні та дослідженні. Е.В. Ільєнков зазначає: «Аристотель здійснює ні що інше, як дослідження законів розвитку всієї духовної культури греків, що йому передувала, дослідження тих колізій $\mathrm{i}$ протиріч, у розгортанні та розв'язанні яких і відбувається завжди процес теоретичного пізнання дійсності» ${ }^{30}$. Стагірит говорить, що людина $\epsilon$ розумною твариною, тому наше пізнання починається з органів відчуттів, із чуттєвого досвіду. На початку «Метафізики» філософ пише: «Досвід здається майже однаковим із наукою та мистецтвом. А наука і мистецтво виникають у людей через досвід. Адже досвід створив мистецтво [науку - Д. К., Л. Г.], як говорить Пол, - і правильно говорить, - а недосвідченість - випадок. 3'являється ж мистецтво тоді, коли на підставі набутих на досвіді думок утворюється один загальний погляд на предмети» ${ }^{31}$. І далі продовжує: «<... ми бачимо, що ті, хто мають досвід успішніші за тих, хто мають одволікле знання (logon echein), проте не мають досвіду. Причина цього у тому, що досвід $\epsilon$ знанням одиничного, а мистецтво - знанням загального. $<\ldots>$ науки про умоглядне (theoretikai) - вище мистецтв творіння (poietikai)» ${ }^{32}$. Коли ми отримуємо чуттєвий досвід (грец. етреiria), наша свідомість може утворювати із нього абстракцію (грец. аphaeresis - одволіклість). Оскільки, згідно 3 Аристотелем, мислення починається із спостережень, першою проблемою у цьому мисленні постає зміна. Філософська думка, яка передує Аристотелю, протиставляє зміну та буття. Аристотель, заперечуючи «теорію ідей» Платона, яка суттєво виходить із вчення піфагорійців, шукає нові способи вираження буття у поняттях, дає власне тлумачення буття і сутності. Всі значення сущого самого по собі він зводить до поняття сутності як єдиного. Підставою для такого зведення є позиція, відповідно до якої бути мати закінчену смислову визначеність, а мати закінчену смислову

\footnotetext{
${ }_{28}^{28}$ Аристотель. Сочинения в четырех томах. Т. 1 / Ред. В.Ф. Асмус. Москва : «Мысль», 1976. (АН СССР. Ин-т философии. Филос. наследие). С. 266.

${ }^{29}$ Там само. С. $118,120$.

${ }^{30}$ Ильенков Э.В. Диалектическая логика: Очерки истории и теории. 2-е изд., доп. Москва : Политиздат, 1984. C. 15.

${ }_{31}$ Аристотель. Сочинения в четырех томах. Т. 1 / Ред. В.Ф. Асмус. Москва : «Мысль», 1976. (АН СССР. Ин-т философии. Филос. наследие). С. 65-66.

${ }^{32}$ Там само. С. 66-67.
} 
визначеність означає бути. Аристотель розробляє вчення про дві форми буття - буття можливого, потенційного (грец. dynamis) та буття дійсного, актуального (грец. energeia). При цьому потенційне буття не $\epsilon$ небуттям і не $\epsilon$ повним буттям. Вказане напрацювання дає змогу Аристотелю пояснити зміну як перехід від потенційного буття до буття в дії. Для пояснення суті змін, яким піддається усе в світі, ми маємо думати, що у кожному конкретному випадку є те, що змінюється: «<..> те, що втрачає що-небудь, має [ще] щось із того, що втрачається, і щось із утворюваного вже має бути. I взагалі, якщо щось знищується, має бути наявним щось суще, а якщо щось виникає, то має існувати те, із чого воно виникає, i те, чим воно породжується, і це не може йти у безкінечність» ${ }^{33}$. І далі пояснює: «<... те, що змінюється, необхідно є сущим, адже зміна відбувається із чогось у щось» ${ }^{34}$. Те, що змінюється, Аристотель називає «усія» (грец. оуsіa - те, що існує, від дієслова to einai - бути): «<...> суть буття кожної речі, позначенням якої $\epsilon$ iї визначення, так само називається іiі сутністю» ${ }^{35}$. Під сутністю Аристотель розуміє самодостатнє одиничне буття. Сутність не може мати загального буття, оскільки загальне $\epsilon$ загальним для багатьох речей. Одиничне буття він розуміє як необхідне, об'єктивне, незалежне від свідомості людини буття як предмет пізнання, що відбувається у поняттях. Оскільки буття стає предметом пізнання, воно вже породжує поняття про буття та стає змістом поняття.

У сущому Аристотель вводить розрізнення на матерію (грец. hylē - ліс, деревина; речовина, матеріал) та форму (грец. morphē - вигляд, образ). При цьому матерія і форма не існують самі по собі, вони $\epsilon$ певними аспектами сущого, тобто всередині сущого розрізняються мисленням: «<... будучи визначеним щось, може бути відокремлене [від матерії тільки подумки], а такі образ, або форма, кожної речі» ${ }^{36}$. Він вказує на змогу філософії, науки, що базується на нашій здатності у мисленні прийняти форму без матерії, тобто мислити форму безвідносно до речей.

Аристотелем форма розуміється як 1) просторова форма та 2) сутність. Просторова форма входить у сутність, що призводить до постійного ототожнення форми та сутності. При цьому просторова форма є одиничним сущим (єдністю форми та матерії, тобто втіленою формою): «Те, що позначено як форма чи сутність, не виникає, а виникає поєднання, яке отримує від неї своє найменування, і що в усьому що виникає є матерія, так

\footnotetext{
${ }^{33}$ Аристотель. Сочинения в четырех томах. Т. 1 / Ред. В.Ф. Асмус. Москва : «Мысль», 1976. (АН СССР Ин-т философии. Филос. наследие). С. 137.

34 Там само. С. 144.

35 Там само. С. 157.

36 там само. С. 157.
} 
що одне [у ньому] є матерія, а інше - форма» ${ }^{37}$. А сутність $є$ формою, що дана у своєму визначенні. Тільки сутності існують відокремлено, а все інше існує лише через них. Філософ зазначає: «<..> під сутністю без матерії я розумію суть буття речі» ${ }^{38}$. Під формою Аристотель розуміє: 1$)$ «<... образ у речі, що чуттєво сприймається $\left\langle\ldots>{ }^{39} ; 2\right)$ «<... суть буття речі» ${ }^{40}$. Він говорить: «<...> матерія буває і такою, що сприймається відчуттями, і такою, що осягається розумом» ${ }^{41}$, i в той же час підкреслює, що: «<..> матерія $\epsilon$ щось невизначене $<\ldots>»{ }^{42}$. Таким чином, сутність, що сприймається чуттєво, - це: 1) сутність як матерія; 2) сутність як форма (дійсність); 3) сутність, що складається із матерії та форми: «<...> сутність кожної речі є «єдине», <..> за своєю сутністю $є$ сущим ${ }^{43}$. Форма щодо буття $\epsilon$ сутністю речі, а щодо пізнання - поняттям про річ, визначеннями самої по собі наявної речі, що можуть бути сформульовані у понятті про річ. Форму Аристотель визначає як загальне. Якщо ж до форми приєднається щось одиничне (матерія), здатне бути вираженим поняттям, вона стане формою одиничного. При цьому загальне (форма) стане визначеністю іншого буття, а саме формою матерії. На відміну від матерії, що є буттям «у можливості», форма є «дійсністю», тобто здійсненням можливості.

Під матерією Аристотель розуміє: 1) «чисту можливість», оскільки форма $\epsilon$ відсутньою («перша матерія»); 2) здійснену можливість, оскільки наявною $\epsilon$ певна форма («остання матерія»). Аристотель розрізняє «першу матерію» та «останню матерію» у зв'язку із тим, що для нього матерія, 3 якої виникають чотири фізичні елементи (вогонь, повітря, вода та земля), вже не має жодних визначених ознак. Оскільки суть цієї матерії не може бути вираженою ні в якому понятті, тому така матерія може розглядатися лише як «можливість» дійсності та не може розглядатися як дійсність: «Якщо ж $є$ щось перше, про що вже не говориться із посиланням на інше як про зроблене із цього іншого, то воно перша матерія $<\ldots .>{ }^{44}$. «Остання матерія» $\epsilon$ не тільки можливістю тієї чи іншої «форми», але й особливою «дійсністю». Зазначена матерія має особливі ознаки, тому щодо неї може бути дано визначення, сформульовано ії поняття. Філософ вважає, що при чуттєвому сприйнятті речей людиною форми матеріальних об'єктів досягають органів відчуттів і сприймаються ними: «Щодо будь-якого

\footnotetext{
${ }^{37}$ Аристотель. Сочинения в четырех томах. Т. 1 / Ред. В.Ф. Асмус. Москва : «Мысль», 1976. (АН СССР. Ин-т философии. Филос. наследие). С. 201.

38 Там само. С. 199.

${ }^{39}$ Там само. C. 201.

40 там само. С. 207.

${ }^{41}$ там само. С. 209.

42 Там само. С. 210.

${ }^{43}$ там само. C. 247.

44 там само. С. 244.
} 
відчуття необхідно взагалі визнати, що воно є тим, що здатне сприймати форми того, що відчувається без його матерії $<\ldots>>{ }^{45}$. Мислення він визначає як досягнення формою розуму без наявності необхідного спеціального органу і, відповідно, матерії: «Мислення <..> має бути здатним сприймати форми, тобто у можливості має бути таким, яким є те, що осягається розумом $<\ldots>$. Адже в іншому випадку він $<\ldots>$ мав би якийнебудь орган, як має його здатність відчуття, проте нічого такого немає» ${ }^{46}$. Увесь світ складається із матерії та форми. Отже, матерія сама по собі є лише можливістю; тільки із набуттям певної форми вона отримує дійсність. Засвоєнням матерією різноманітних форм пояснюється рух або зміна. Матерія - рухоме, форма - рушійне. Тому будь-який рух має подвійну причину - матеріальну, механічну, через необхідність, i формальну, телеологічну, заради мети. Аристотель доводить, що рух не виключає буття, а навпаки, буття $\epsilon$ наявним у русі. Для нього форма і матерія стають метафізичним і пояснювальним принципами. Таким чином, визнанням взаємозумовленості матерії та форми Аристотель примирює теорію Демокрита із теорією Платона.

\section{3. Гносеологія понять}

Особливості світогляду Аристотеля, що зароджується на засадах платонізму, проявляються як у стилі його філософствування, так і в його філософії. Про взаємозв'язок між платонізмом та філософією Аристотеля С.М. Трубецькой пише: «Істинне знання є логічним знанням, що досягається за допомогою дослідження понять, їх утворення і поєднання. Поняттями осягається дійсне у речах, їхня незмінна сутність, їхня кінцева основа, загальне і необхідне в них. I ця сутність речей те, що в них істинне та

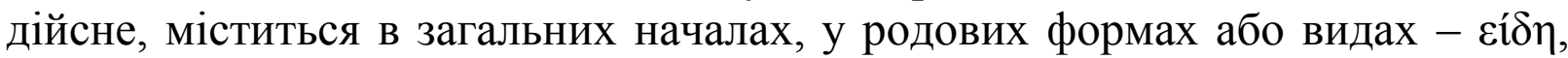
які становлять зміст наших понять. <...> Філософія Аристотеля $\epsilon$ так само, як філософія Сократа і Платона, наукою поняття. Все одиничне, окреме зводиться індуктивним шляхом до загальних понять» ${ }^{47}$. Г.В.Ф. Гегель надає характеристику способу філософствування Аристотеля в аспекті нашого дослідження: «Аристотель <..> бере усі ці одиничні явища <..> та переробляє їх таким чином, що із них виникає глибоченне спекулятивне поняття. $<\ldots>$ Коли ж < ..> він починає, навпаки, із загального, простого, i переходить до його визначення, то це також виглядає у нього так, ніби він перераховує безліч значень, в яких це загальне зустрічається, і після

\footnotetext{
45 Аристотель. Сочинения в четырех томах. Т. 1 / Ред. В.Ф. Асмус. Москва : «Мысль», 1976. (АН СССР Ин-т философии. Филос. наследие). С. 421.

46 Там само. С. 433.

47 Трубецкой С.Н. История древней философии. Часть вторая. Москва : Типолитография Товарищества И.Н. Кушнерев и Ко, 1908. С. 59-60.
} 
розгляду всіх їх він знову оглядає всі їхні форми, не оминаючи навіть найбуденніші та чуттєві» ${ }^{48}$.

У «Метафізиці» Аристотель вказує, що піфагорійці були першими, хто почав досліджувати поняття та визначення: «Щодо суті речі вони стали міркувати і давати їй визначення, проте розглядали ії занадто просто. Їхні визначення були поверхневими, і те, до чого найперше підходило зазначене ними визначення, вони і вважали сутністю речі» ${ }^{49}$. Філософ намагається показати, що в людському мисленні $є$ такі засади, що мають загальнолюдське значення та які мають бути завжди дотримані в кожному спорі, що розпочинається 3 метою з'ясування істини: «Треба заперечувати не проти

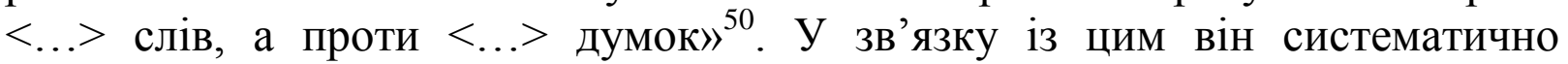
розробляє питання про закони мислення як про основні принципи розумового процесу. Аристотель доходить висновку, що мислення $\epsilon$ неможливим без чуттєвих уявлень: «Оскільки людина подумки споглядає, необхідно, щоб вона одночасно споглядала в образах [грец. phantasmata Д. К., Л. Г.]. Образи являють собою ніби чуттєві враження, тільки без матерії. Уява $\epsilon$ щось інше, ніж твердження і заперечення. Адже істина та неправда $є$ поєднання понять. Завдяки якій відмінній ознаці первинні поняття не будуть збігатися з образами? Або [нехай] ці поняття не образи, але [в усякому разі, вони не можуть проявлятися] без образів» ${ }^{51} .3$ огляду на те, що мисленням завжди щось підтверджується або спростовується, необхідним є використання не тільки чуттєвих образів, але й понять, за допомогою яких лише і можна виявити існування чи неіснування речей. Він пише: «Насправді, наукове і чуттєве знання розподіляються за об'єктами: потенційне знання [зводиться] до об'єктів, наданих у можливості, дійсне знання - до об'єктів в їх реалізованому вигляді. У душі здатність, що чуттєво сприймає і пізнавальна здатності потенційно є цими об'єктами - як чуттєво пізнавальними, так і умосяжними» ${ }^{52}$. Аристотель стверджує, що саме розум (грец. nоys) є началом науки: «Оскільки із станів думки, якими ми осягаємо істину, одні завжди істинні, а інші допускають помилки $<\ldots .>$, наука ж і нус завжди істинні; <...>, а будь-яка наука спирається на доводи, то не може бути науки про начала; а оскільки тільки нус може бути істиннішим за науку, то він буде мати своїм предметом начала $<\ldots>$, а тому i наука не може бути началом науки. Таким чином, якщо окрім науки не

\footnotetext{
${ }^{48}$ Гегель Г.В.Ф. Сочинения: в 14-х т. / пер. с нем. Б.Г. Столпнер. Ленинград : Партийное издательство, 1932. Т. 10, Кн. 2. Лекции по истории философии. С. 236-237.

${ }^{49}$ Аристотель. Сочинения в четырех томах. Т. 1 / Ред. В.Ф. Асмус. Москва : «Мысль», 1976. (АН СССР. Ин-т философии. Филос. наследие). С. 78.

${ }^{50}$ Там само. С. 134.

${ }^{51}$ Аристотель. О душе /Предисл. В.К. Сережникова; перев. и прим. П.С. Попова. Москва : Соцэкгиз, 1937. C. 103.

${ }^{52}$ Там само. С. 102.
} 
маємо ніякого іншого роду істинного [пізнання], то началом науки буде нус. I він буде началом начала, і так само наука як ціле відноситься до [свого] предмета в цілому» ${ }^{53}$. Про співвідношення розуму та закону філософ зазначає: «Отже, хто вимагає, щоб панував закон, очевидно, вимагає, щоб панувало тільки божество і розум, а хто вимагає, щоб панувала людина, привносить до цього i тваринне начало, адже пристрасть $\epsilon$ чимось тваринним і гнів спокушає з істинного шляху правителів, хоча б вони були i найкращими людьми; навпаки, закон - це вільний від несвідомих потягів розум» ${ }^{54}$. А щодо предмета науки вказує: «<..> те, що становить предмет наукового знання (to epistēton), існує з необхідністю, а отже вічно, адже все існуюче з безумовною необхідністю вічне, вічне ж не виникає i не знищується. Далі вважається, що будь-якій науці нас навчають (didaktē), a предмет науки - це предмет засвоєння (mathēton)» 55 .

Філософію та діалектику Аристотель не відриває від окремих наук. Саме за допомогою діалектики філософ шукає загальні визначення в їхній сфері. Діалектика розуміється Аристотелем як метод філософського та наукового дослідження: «Адже, будучи способом дослідження, вона прокладає собі шлях до начал усіх вчень» ${ }^{56}$. Метою цього методу є напрацювання основних загальних визначень буття та мислення. У зв'язку із цим К. Маркс пише: «Вже Аристотель глибокодумно вказав на поверхню методу, який бере за вихідний пункт який-небудь абстрактний принцип, але не допускає самозаперечення цього принципу у вищих формах» ${ }^{57}$.

Як вихідний матеріал для аналізу пізнавальної діяльності людини Аристотель бере слово і доходить висновку, що точне розуміння понять має спиратися на вичерпну фіксацію значень слів: «<..> визначення грунтується на необхідності того, щоб висловлене ним щось означало, адже визначенням буде позначення суті (logos) через слово» ${ }^{58}$. Для нього $€$ неприйнятною ситуація, коли слово має невизначену множинність значень, у слова в ідеалі має бути тільки одне значення, а для кожного предмета має бути лише одне ім'я: «<... якщо мислити щось одне можливо, то для нього можна буде підібрати одне ім'я» ${ }^{59}$.

\footnotetext{
53 Аристотель. Сочинения в четырех томах. Т. 2 / Ред. 3.Н. Микеладзе. Москва : «Мысль», 1978. (АН СССР, Ин-т философии. Филос. наследие). С. 346.

${ }^{54}$ Аристотель. Сочинения в четырех томах. Т. 4 / Общ. ред. А.И. Доватура. Москва : «Мысль», 1983. (АН СССР, Ин-т философии. Филос. наследие). С. 481.

${ }_{55}^{55}$ Там само. С. 175.

56 Аристотель. Сочинения в четырех томах. Т. 2 / Ред. 3.Н. Микеладзе. Москва : «Мысль», 1978. (АН СССР, Ин-т философии. Филос. наследие). С. 351.

57 К. Маркс и Ф. Энгельс. Из ранних произведений. Государственное издательство политической литературы, Москва, 1956. С. 125.

${ }_{58}$ Аристотель. Сочинения в четырех томах. Т. 1/ Ред. В.Ф. Асмус. Москва : «Мысль», 1976. (АН СССР. Ин-т философии. Филос. наследие). С. 142-143.

${ }^{59}$ Там само. С. 127.
} 
Аристотель зазначає, що філософська думка висуває чотири основні начала (причини) буття і світу, два 3 яких: 1) матерія - те, у чому реалізується поняття; 2) форма - поняття, яке приймає матерія, коли відбувається перехід від можливості до дійсності. Поняття про предмет, здійснене у речовині (матерії), $\epsilon$ формою. Для філософа розум не $\epsilon$ однорідним. У ньому маються матеріальне та формальне начала. Перше начало - пасивний розум (грец. noys pathetikos) - розсудок, що взаємодіє із відчуттями, які виявляють у ньому спільність понять. Пасивний розум залежить від зовнішніх речей та діє лише у взаємозв'язку із відчуттями, чуттєвими образами. Тому загальнопонятійне існує у ньому тільки як можливість. Для реалізації такої можливості необхідна активність форми, що притаманна другому началу - діяльному розуму (грец. noys poietikos). Цей активний розум завжди перебуває у дії та впливає на пасивний розум: «Розум через співпричетність предметові думки мислить сам себе: він стає предметом думки, дотикаючись і мислячи його, так що розум і предмет його - одне і те ж. Адже те, що здатне приймати у себе предмет думки та сутність, є розум; а діяльний він, коли володіє предметом думки $<\ldots .>{ }^{60}$. Проміжне положення розсудку між чуттєвим сприйняттям і пізнанням розумом виявляється Платоном, проте цей аспект залишається поза його увагою. Аристотель, навпаки, спеціально звертається до вивчення серединності розсудку, що приводить його до постановки проблеми «середнього» (грец. to meson). Між образністю сприйняття одиничних речей та найзагальнішими поняттями розуму він виділяє серединну область понять. При цьому одиничні сприйняття чуттєвого досвіду у своєму багаторазовому повторенні виявляють загальні поняття розсудку, які й організовують плутанину цих сприйнять. Таким чином, для Аристотеля наукове мислення прояснює мислення розсудку, підсумовує людський досвід й осмислює його за допомогою понять.

Прагнення пізнати сутність речей за допомогою їхніх родо-видових понять приводить Аристотеля до необхідності встановлення відношення загального до одиничного: «Нинішні філософи найімовірніше визнають сутністю загальне (адже роди - це загальне, а роди, на їхню думку, у більшій мірі начала і сутності; оскільки вони шукають, виходячи із визначень); давні, навпаки, вважали сутностями одиничне, наприклад вогонь і землю, а не спільне їм - тіло» ${ }^{61}$. Аристотель, 3 однієї сторони, спростовує «ідеї» Платона як відчужені загальності, а з іншої - їх постулює, оскільки знання за його вченням $є$ можливим як знання загального. Якщо пізнання

\footnotetext{
${ }^{60}$ Аристотель. Сочинения в четырех томах. Т. 1 / Ред. В.Ф. Асмус. Москва : «Мысль», 1976. (АН СССР. Ин-т философии. Филос. наследие). С. 310.

${ }^{61}$ Там само. С. 300.
} 
починається 3 одиничного, воно $\epsilon$ «першим для нас» (грец. proteron pro hemas), а якщо із загального, що становить суть знання, воно є «першим по природі» (грец. proteron te fusei). Осмислення єдності загального та одиничного надає змогу Аристотелю говорити про те, що кожна окрема одинична річ являє собою єдність «першооснови» та іiі «форми». При цьому «форма» речі є видовою або родовою визначеністю мінімальної спільності, результатом іiі усвідомлення. Цю проблему він формулює так: «<..> якщо нічого не існує окрім одиничних речей, - а таких речей безліч, - то як можна досягти знання про цю незліченну множину? Адже ми пізнаємо всі речі остільки, оскільки у них є щось єдине і тотожне й оскільки їм притаманне щось спільне» ${ }^{62}$. Та наводить $\dddot{11}$ розв’язок: «Справа у тому, що знання, так само як і пізнання, подвійне: з одного боку, це те, що мається у можливості, а 3 іншого - у дійсності. Так ось можливість, будучи як матерія загальною та невизначеною, належить до загального і невизначеного, а дійсність, будучи визначеною, належить до визначеного <..>» ${ }^{63}$. Подібно до того, як у природі речей загальне, тобто сутність речі, що виражається у понятті, є причиною та підставою для визначення одиничного, так само найперше завдання пояснювальної науки полягає у виведенні одиничного iз загального і, таким чином, розумінні необхідності емпірично дійсного світу: «<..> для урозуміння через визначення раніше загальне, а для чуттєвого сприйняття - одиничне. I для урозуміння через визначення привхідне раніше цілого, <..> адже визначення як ціле неможливе без частини $<\ldots>\gg{ }^{64}$. На думку Аристотеля, основне питання філософії - щодо поняття про сутність буття - може бути розв'язане лише у зв'язку із роз'ясненням фактів дійсності: «Необхідно вимагати не визнання того, що щось $є$ або не $\epsilon$, а щоб сказане $<\ldots>$ щось означало, так що $<\ldots>$ слід виходити із визначення $<\ldots>$.. ${ }^{65}$. Логічною формою цих рішень, до яких прагне наука, є визначення поняття (грец. horismos): «<..> будь-яке вивчення відбувається через попереднє знання усіх [передумов] або деяких: <..> i вивчення через визначення, адже частини, що складають визначення, необхідно знати заздалегідь і вони мають бути доступними» ${ }^{66}$. У визначенні поняття встановлюється, по-перше, неминуща сутність кожного одиничного явища (грец. oysia, to ti èn einai), як причина його змінюваних станів і діяльності (грец. ta symbebēkota), по-друге, зазначається його залежність, як поняття, від іншого більш загального родового поняття та вказується відмінна ознака.

\footnotetext{
${ }^{62}$ Аристотель. Сочинения в четырех томах. Т. 1 / Ред. В.Ф. Асмус. Москва : «Мысль», 1976. (АН СССР. Ин-т философии. Филос. наследие). С. 109.

${ }^{63}$ Там само. С. 349.

${ }^{64}$ Там само. С. 161.

65 Там само. С. 143.

${ }^{66}$ Там само. С. 92.
} 
Визначення найвищих родових понять не виводяться, а лише роз'яснюються. Таким чином, на вершині системи понять в Аристотеля не знаходиться одне найвище поняття, як у Платона - ідея блага, а вона завершується вищими родовими поняттями, родами висловлювання категоріями. У вченні про категорії Аристотель синтезує форми всього сущого та форми його словесного вираження. Він розглядає загальне та поняття в їхній єдності, оскільки загальне знаходиться в бутті та речах. Істину ж філософ вбачає у відповідності думки дійсності: «Адже залежно від того, чи існує річ, чи ні, поняття береться за істинне або за неістинне» ${ }^{67}$. Поняттям дійсних речей ми приписуємо дійсність, тобто ми розглядаємо поняття, не відволікаючись від дійсності (як Платон розглядав свої «ідеї»), а як реалізовані в дійсності, у певній матерії: «<..> визначення і пізнання [того, що у дійсності], має передувати пізнанню [того, що у можливості]» ${ }^{68}$.

Аристотель зазначає, що визначення через зазначення складових частин речі $\epsilon$ річ у можливості, оскільки частини речі - матерія. Визначення через зазначення мети речі (для чого ця річ) $є$ річ у здійсненні (у дійсності). Поєднання складових частин речі (матерії) із метою речі (формою) також $\epsilon$ визначенням. Аристотель говорить про складові частини поняття: «Частиною називається <..> те, що входить у визначення, яке роз'яснює кожну річ, також $\epsilon$ частини цілого; тому рід називається і частиною виду, хоча в іншому смислі вид - частина роду» ${ }^{69}$. Визначення, згідно 3 Аристотелем, не може бути вірним, якщо: 1) поняття про предмет хибне; 2) визначення не підведене під родову відмінність; 3) визначення не належить до відмінності предмета, що визначається; 4) визначення не виражає сутності предмета; 5) форма визначення $\epsilon$ неправильно вираженою. Головною метою визначення $є$ досягнення ясності пізнання, тому воно має складатися за допомогою зрозумілих виразів.

Щодо пізнання неподільних понять Аристотель зазначає: «Їх пізнають певним чином через протилежне їм. Пізнавальне ж має бути у можливості цими протилежностями, i [разом із тим] у ньому має бути єдине. Якщо ж щось не має протилежного собі, то воно пізнає саме себе, $\epsilon$ [завжди] дійсність та існує окремо» ${ }^{70}$. Крім того, підкреслює: «Взагалі поняття <...> слід виводити із поняття протилежного» ${ }^{71}$. Зокрема, наводить визначення понять «справедливість» і «несправедливість»: «Справедливість (dicaiosyn) - така чеснота, з огляду на яку кожен володіє тим, що йому належить, і так,

\footnotetext{
${ }^{67}$ Аристотель. Категории. Перевод А.В. Кубицкого. Москва : ГСЭИ, 1939. С. 45.

${ }^{68}$ Аристотель. Сочинения в четырех томах. Т. 1 / Ред. В.Ф. Асмус. Москва : «Мысль», 1976. (АН СССР. Ин-т философии. Филос. наследие). С. 245.

${ }^{69}$ Там само. С. 174.

${ }^{70}$ Там само. С. 437.

71 Тахо-Годи А.А. Античные риторики / Под ред. А.А. Тахо-Годи. Москва : Изд-во Моск. Ун-та, 1978. С. 77.
} 
як велить закон, а несправедливість - така якість, 3 огляду на яку люди у небезпеці роблять прекрасні справи, керуючись законом і підкорюючись йому $<\ldots>\gg{ }^{72}$. Також зазначає: «При цьому достатніми слід вважати ті визначення, які щодо кожного даного предмета не видаються ні занадто невизначеними, ні занадто дріб'язковими» ${ }^{73}$. Аристотель, говорячи про пробіли як недоліки писаних законів, вказує: «Їхні визначення мають відрізнятися характером загальності <..>. Те ж саме можна сказати про випадки, відносно яких складно давати які-небудь вказівки через їхню безмежність <..>. Коли, таким чином, не можна дати точного визначення, $<\ldots>$ у таких випадках слід уживати загальні вирази» ${ }^{74}$. Філософ зазначає, що міркувати про справедливість необхідно, з огляду на те, чи є вона благом чи ні - «слід говорити на підставі того, що міститься у понятті справедливості та блага» ${ }^{75}$.

Аристотель за допомогою понятійного мислення синтезує цілі, наявні в живій природі, які $є$ зовнішньою необхідністю для кожного індивіда, та процеси і форми цілевизначення в життєдіяльності людини, в тому числі у сфері права. Філософське i наукове значення для людства досягнень Аристотеля у природно-історичному описі явищ мислення у поняттях підсумовує Г.В.Ф. Гегель: «Безсмертна заслуга Аристотеля, яка має наповнювати нас найвеличнішим почуттям захоплення силою цього розуму, полягає у тому, що він першим здійснив такий опис» ${ }^{76}$.

\section{ВИСНОВКИ}

3 Аристотелем принципово змінюється підхід до мови філософії та науки, 3'являється нова порівняно з Платоном манера мислити та писати. Для Аристотеля філософія та наука на шляху пізнання (визначення) своїх основних понять мають вивільнитися від багатозначності доведенням мови до такого ступеня ясності, щоб у підсумку отримати одне визначене їхнє значення. Філософ доходить висновку, що знання має справу із поняттям, яке містить у собі істотні визначення предмета. Мислення у поняттях як результат творчої дії людського розуму стає для Аристотеля мовою філософії та науки. Він описує генезис ідеї науки та їі глибоку укоріненість у первісному мотиві людського буття. Учення Аристотеля про матерію та форму як про можливість і дійсність розкриває співвідношення форм речей та форм мислення.

\footnotetext{
72 Тахо-Годи А.А. Античные риторики / Под ред. А.А. Тахо-Годи. Москва : Изд-во Моск. Ун-та, 1978. С. 43.

${ }^{73}$ Там само. С. 51.

74 Там само. С. 61.

75 Тахо-Годи А.А. Античные риторики / Под ред. А.А. Тахо-Годи. Москва : Изд-во Моск. Ун-та, 1978. С. 110.

${ }^{76}$ Гегель Г.В.Ф. Наука логики. В 3-х т. Т. 3. Москва : «Мысль», 1972. (АН СССР. Ин-т философии. Филос. наследие). С. 30.
} 
Аристотель критикує «теорію ідей» Платона та включає іії інтерпретацію в контекст своєї філософської системи. Він переносить платонівські ідеї на рівень понятійної експлікації - переносить ідею речі у саму річ, що призводить не до уречевлення ідеї, а до ідеалізування матерії. Мислення Аристотеля характеризується тим, що матеріальна річ отримує в нього самостійне значення та стає предметом самодостатнього споглядання. На відміну від Платона з його теорією пізнання ідеального світу, Аристотель звертається до пізнання світу дійсності та досвіду. Загальне і поняття він розглядає в їх єдності, оскільки загальне, по-перше, знаходиться у бутті та речах, а по-друге, воно $є$ принципом вираження смислу. Істину філософ вбачає у відповідності думки дійсності. Аристотель доходить висновку, що метафізичну реальність необхідно шукати у середині між родовим і чуттєвим образами, тобто в одиничній речі, визначеній через іï поняття. Зазначеного він досягає введенням відношення матерії до форми чи можливості до дійсності. Сполучну ланку між загальною сутністю речей, яка виражається у понятті, та їхнім окремим явищем, що сприймається, Аристотель знаходить у принципі розвитку. Поняття буття він визначає як таке, що саме себе реалізує, та є готовим перейти від можливості до дійсності. Таким чином, у бутності незмінна первинна сутність речей переходить від стану чистої можливості до дійсності. Цей процес відбувається тоді, коли матерія, що містить у собі всі можливості, формується в належну їй у вигляді здатності форму. Отже, кінцевим об'єктом наукового пізнання не є ані одиничний образ чуттєвого сприйняття, ані одволіклість. Таким об'єктом для Аристотеля $\epsilon$ одинична річ, яка в потоці власних чуттєвих зовнішніх проявів зберігає свою сутність, що виражається в понятті. При цьому він стверджує, що родові поняття не мають ніякої сутності.

Аристотель підбиває методологічний підсумок досягненням попередніх філософів у пізнанні природи та людини, поясненні людського мислення, зокрема, у сфері права. Він синтезує окремі ідеї та вчення, систематизує попередню та сучасну йому давньогрецьку філософію і науку. Встановлено, що Аристотель переосмислює й уточнює деякі поняття попередніх філософів, а також вводить цілу низку нових понять у створену ним систему знань, що охоплює всі сторони давньогрецької філософії та науки класичного періоду, у тому числі науки права.

\section{АНОТАЦІЯ}

Філософія Аристотеля та його понятійний світогляд стають великою прикордонною віхою між класичним періодом давньогрецької філософії, коли формулюються всі її найважливіші принципи, та елліністичною добою, коли характер філософствування в аспекті понятійного мислення стає істотно 
іншим. Накопичення та поглиблення знань приводить до переходу від споглядального знання до більш конкретно наукового знання. 3 цього погляду Аристотель постає перед нами як великий організатор наукового знання. Якщо наукова компонента платонівської школи вичерпується математикою, запозиченою від піфагорійців, то в Аристотеля широко розвивається наука як дослідно-теоретичне вивчення реального світу. Філософ вважає науковим лише те пізнання, що здатне у всьому одиничному знаходити загальні принципи. Будь-яка загальність для Аристотеля має значення тільки тоді, коли вона сама перебуває у становленні та діє i приводить у рух матеріальні речі. При цьому кожна річ є матерією, ейдосом, виявляє своє причинне походження та своє цільове призначення. Таким чином, об'єктивізм усього існуючого, що в Аристотеля набуває форми одволікло-загального становлення понять, визначає подальший перехід понятійного мислення до суб'єктивізму елліністичної доби.

\section{ЛІТЕРАТУРА}

1. Маркс К. Капитал. Т. І. Маркс К., Энгельс Ф. Соч. 2-е изд., т. 23. Москва. 1960. $907 \mathrm{c.}$

2. Лосев А.Ф. Очерки античного символизма и мифологии / Сост. А.А. Тахо-Годи; общ. ред. А.А. Тахо-Годи и И.И. Маханькова. Москва : Мысль. 1993.959 с.

3. Лосев А.Ф. История античной эстетики. Аристотель и поздняя класика. Харьков : Фолио; Москва : ООО «Издательство АСТ», 2000. 880 с. (Вершины человеческой мысли).

4. Ленин В.И. Полное собрание починений. Издание пятое. Том 29. Философские тетради. Москва : Издательство политической литературы, 1969. $783 \mathrm{c.}$

5. Аристотель. Сочинения в четырех томах. Т. 1 / Ред. В.Ф. Асмус. Москва : «Мысль», 1976. 550 с. (АН СССР. Ин-т философии. Филос. наследие).

6. Трубецкой С.Н. История древней философии. Часть вторая. Москва : Типолитография Товарищества И.Н. Кушнерев и Ко, 1908. 142 с.

7. Гегель Г.В.Ф. Сочинения: в 14-х т. / пер. с нем. Б.Г. Столпнер. Ленинград : Партийное издательство, 1932. Т. 10, Кн. 2. Лекции по истории философии. $454 \mathrm{c}$.

8. Ильенков Э.В. Диалектическая логика: Очерки истории и теории. 2-е изд., доп. Москва : Политиздат, 1984. 320 с.

9. Аристотель. О душе / Предисл. В.К. Сережникова; перев. и прим. П.С. Попова. Москва : Соцэкгиз, 1937. XXIV, 179 с. 
10. Аристотель. Сочинения в четырех томах. Т. 2 / Ред. 3.Н. Микеладзе. Москва : «Мысль», 1978. 687 с. (АН СССР, Ин-т философии. Филос. наследие).

11. Аристотель. Сочинения в четырех томах. Т. 4 / Общ. ред. А.И. Доватура. Москва : «Мысль», 1983. 830 с. (АН СССР, Ин-т философии. Филос. наследие).

12. К. Маркс и Ф. Энгельс. Из ранних произведений. Государственное издательство политической литературы, Москва. 1956. 699 с.

13. Аристотель. Категории / Перевод А.В. Кубицкого. Москва : ГСЭИ, 1939. $84 \mathrm{c}$.

14. Тахо-Годи А.А. Античные риторики / Под ред. А.А. Тахо-Годи. Москва : Изд-во Моск. Ун-та, 1978. 352 с.

15. Гегель Г.В.Ф. Наука логики. В 3-х т. Т. 3. Москва: «Мысль», 1972. (АН СССР. Ин-т философии. Филос. наследие). 371 с.

Information about authors: Kucherenko D. S., Legal Counsel "COMREC LTD" 177-A, Culturna str., Zaporizhzhia, 69040, Ukraine

Hamburh L. S., Ph.D. in Law Sciences, Associate Professor, Assistant Professor at the Social Medicine, Public Health, Medical and Pharmaceutical Law Department Zaporizhzhia State Medical University 26, Maiakovskyi avenue, Zaporizhzhia, 69035, Ukraine 